\title{
Separation of Sublethal and Lethal Effects of the Bactericidal/Permeability Increasing Protein on Escherichia coli
}

Brian A. Mannion, Jerrold Weiss, and Peter Elsbach

Departments of Microbiology and Medicine, New York University School of Medicine, New York 10016

\begin{abstract}
Binding of the bactericidal/permeability increasing protein (BPI) of granulocytes to Escherichia coli promptly produces several discrete outer envelope alterations and growth arrest without major impairment of bacterial structure or biosynthetic capabilities, raising the question whether these early effects of BPI are sufficient to cause bacterial death. In this study, the bactericidal action of BPI was examined more closely. We have found that bovine or human serum albumin blocks bacterial killing without preventing BPI binding or an increase in outer membrane permeability. Moreover, addition of serum albumin after BPI results in growth resumption without displacement of bound BPI and without (early) repair of the envelope alterations. These effects are opposite to those produced by $\mathrm{Mg}^{2+}(80 \mathrm{mM})$, which displaces $>85 \%$ of bound BPI and rapidly initiates outer envelope repair without restoration of bacterial growth. The extent of rescue by serum albumin depends on the time and $\mathrm{pH}$ of preincubation of BPI with $E$. coli: e.g., for $E$. coli $\mathrm{J5}$ treated with human BPI, $t_{1 / 2}=79$ min at pH 7.4 and $10 \mathrm{~min}$ at pH 6.0. The serum albumin effects on BPI action are the same in wild-type $E$. coli and in a mutant strain lacking an activatable phospholipase, indicating that serum albumin does not act by sequestering membrane-damaging products of bacterial phospholipid hydrolysis. The progression from reversible to irreversible growth arrest, revealed by the subsequent addition of serum albumin at different times, is paralleled by a decrease in amino acid uptake and an increase in the permeability of the cytoplasmic membrane to $o$-nitrophenyl- $\beta$-D-galactoside. These findings demonstrate at least two stages in the action of BPI: $(a)$ an early, reversible, sublethal stage in which BPI has effects on the outer envelope and causes growth arrest, and (b) time- and pH-dependent progression to a lethal stage, apparently involving cytoplasmic membrane damage, possibly caused by penetration of a small subpopulation of BPI. (J. Clin. Invest. 1990. 85:853-860.) bacterial inner membrane $\bullet$ bacterial outer membrane $\bullet$ bactericidal mechanisms • granulocytes • growth inhibition • serum albumin
\end{abstract}

Portions of this work were presented at the Annual Meeting of the American Federation for Clinical Research, Washington, DC, 28 April-1 May 1989, and published in abstract form. (Clin. Res. 1989. 37:435a.)

Address reprint requests to Dr. Elsbach, Department of Medicine, New York University Medical Center, 550 First Avenue, New York, NY 10016.

Received for publication 26 May 1989 and in revised form 14 September 1989.

J. Clin. Invest.

(C) The American Society for Clinical Investigation, Inc. 0021-9738/90/03/0853/08 $\$ 2.00$

Volume 85, March 1990, 853-860

\section{Introduction}

The bactericidal/permeability increasing protein (BPI) ${ }^{1}$ is a potent cytotoxin of polymorphonuclear leukocytes that acts specifically against Gram-negative bacteria (1-3). At lethal doses, binding of BPI to target cells is followed almost immediately by growth arrest and a number of discrete outer membrane alterations, including an increase in outer membrane permeability to normally impermeant drugs such as actinomycin D (actD) (1, 4-6). Remarkably, bacterial growth arrest occurs despite continued macromolecular synthesis for at least $60 \mathrm{~min}$, indicating that initially, BPI causes little gross functional or structural damage $(1-5,7,8)$. In fact, addition of high concentrations of divalent cations $\left(\mathrm{Mg}^{2+}\right.$ or $\left.\mathrm{Ca}^{2+}\right)$ or trypsin to BPI-treated bacteria removes the bulk of the bound BPI and initiates rapid ( $15 \mathrm{~min}$ ) repair of the outer envelope damage by active biosynthesis but does not restore bacterial growth (8-10), further demonstrating the remarkable integrity of BPItreated bacteria.

The reversibility of these outer membrane alterations suggests that the bactericidal action of BPI is mediated by other (additional) lesions on the target bacterium. The nature, sites, and timing of these effects have yet to be elucidated. The prolonged preservation of normal cellular functions despite prompt growth arrest may mean that the bactericidal action is due to an extraordinarily discrete but lethal lesion inflicted very early after binding with little or no effect on overall bacterial structure or biosynthetic capabilities. Alternately, BPI may initially cause only sublethal damage sufficient to arrest growth but killing is the consequence of later events such as BPI processing, BPI penetration, or as yet unidentified biochemical lesions.

We now show that the early consequences of BPI treatment on target bacteria including surface binding, outer membrane alterations and growth arrest can be uncoupled from bacterial killing, indicating that the early interactions of BPI with the bacterial outer envelope are sublethal. Progression from sublethal to lethal damage is slow at neutral $\mathrm{pH}$ but is accelerated at $\mathrm{pH} 6.0$ and is accompanied by apparently irreversible loss of cytoplasmic membrane-associated functions, suggesting that the cytoplasmic membrane is the site where BPI ultimately inflicts its lethal lesion.

\section{Methods}

\section{Chemicals}

Bovine serum albumin (BSA) (Fraction V) and pig serum albumin (Fraction V) were obtained from United States Biochemical Corp. (Cleveland, $\mathrm{OH}$ ), endotoxin-free BSA, heparin sulfate, and chondroi-

1. Abbreviations used in this paper: ActD, actinomycin D; BPI, bactericidal/permeability increasing protein; OM, outer membrane; ONP, $o$-nitrophenol; ONPG, $\alpha$-nitrophenyl- $\beta$-D-galactopyranoside. 
tin sulfates A, B, and C from Calbiochem-Behring Corp. (La Jolla CA), human serum albumin from Mann Research Laboratories (New York), chicken egg albumin (ovalbumin) from Pfaltz \& Bauer, Inc., (Waterbury, CT) actinomycinD (actD) from Merck Sharp, and Dohme (West Point, PA), chloramphenicol sodium succinate from Parke-Davis Co. (Morris Plains, NJ), fatty-acid free BSA, carboxymethyl BSA, gamma globulin (bovine), poly-aspartate $(15,000-50,000$ mol wt), and $o$-nitrophenyl- $\beta$-D-galactopyranoside (ONPG) from Sigma Chemical Co. (St. Louis, MO) U- $\left[{ }^{14} \mathrm{C}\right]-\mathrm{L}$-amino acid mixture ( $56 \mathrm{mCi} / \mathrm{mmol}$ ) from New England Nuclear (Boston, MA), and $\left[(3,4)-{ }^{3} \mathrm{H}\right]-\mathrm{L}-$ proline $(51 \mathrm{Ci} / \mathrm{mmol})$ from ICN Radiochemicals (Cleveland, $\mathrm{OH}$ )

\section{Purification and radiolabeling of BPI}

Human BPI and rabbit BPI were purified as previously described (11, 12) and stored in $50 \mathrm{mM}$ sodium acetate/acetic acid buffer $\mathrm{pH} 4.0$ Human BPI was labeled with ${ }^{125} \mathrm{I}$ as described previously (11).

\section{Preparation of human serum}

Venous blood was collected from healthy volunteers after informed consent. The serum was collected after clot formation, centrifuged at $10,000 \mathrm{~g} / 20 \mathrm{~min}$ to remove any debris, and stored at $-70^{\circ} \mathrm{C}$. Heattreated serum was prepared by incubating the serum at $56^{\circ} \mathrm{C}$ for 45 min before storage at $-70^{\circ} \mathrm{C}$

\section{Bacterial strains and growth conditions}

Escherichia coli J5, a rough UDP-galactose-4-epimerase negative mutant of the smooth strain 0111-B4, and the smooth strains $E$. coli ML-35 (i- $\left.\mathbf{y}^{-}, \mathrm{z}^{+}\right)$(a generous gift of R. Lehrer, Department of Medicine, UCLA Center for the Health Sciences, Los Angeles, CA) and $E$. coli $\mathrm{O} 9$ were grown in triethanolamine buffered $(\mathrm{pH}$ 7.7-7.9) minimal salts medium (13). Other rough strains of E. coli, PL2, 1602, and 1303, (a pldA ${ }^{-}$mutant of strain 1602 lacking the detergent-resistant phospholipase A [14]), and the smooth strain E. coli 0111:B4 were grown in physiological saline supplemented with $0.8 \%(\mathrm{wt} / \mathrm{vol})$ nutrient broth (Difco Laboratories, Detroit, MI). A clinical isolate of $E$. coli containing $\mathrm{K} 1$ capsule (a generous gift of Alan Cross, Department of Medicine, Walter Reed Hospital, Washington, DC) was grown in yeast broth (15). Overnight cultures were transferred to fresh medium (diluted $1 / 10)$ and grown to mid-to-late logarithmic phase $(\sim 3 \mathrm{~h})$ at $37^{\circ} \mathrm{C}$. Bacterial concentrations were determined by absorbance at 550 $\mathrm{nm}$ using a Coleman Junior spectrophotometer. The bacteria were sedimented in a clinical centrifuge and resuspended to a final concentration of $1 \times 10^{9}$ cells per $\mathrm{ml}$ in sterile physiological $(0.9 \%)$ saline. For amino acid uptake experiments, the cells were used immediately; for all other experiments, the cells were used within $1 \mathrm{~h}$ of harvesting.

\section{Bioassays of BPI}

The standard incubation mixture contained $E$. coli at $4 \times 10^{7}$ cells $/ \mathrm{ml}$ in sterile physiological $(0.9 \% \mathrm{wt} / \mathrm{vol})$ saline containing $0.8 \%(\mathrm{wt} / \mathrm{vol})$ nutrient broth buffered with $20 \mathrm{mM} \mathrm{NaH} \mathrm{PO}_{4} / \mathrm{Na}_{2} \mathrm{HPO}_{4}$ at the indicated $\mathrm{pH}$.

Measurement of bacterial viability. After the indicated incubation at $37^{\circ} \mathrm{C}$, aliquots of the bacteria were serially diluted 10,000 -fold in sterile isotonic saline containing $4 \mathrm{mM} \mathrm{MgCl}_{2}$ (to prevent further BPI binding [10]) and $400 \mu \mathrm{g} / \mathrm{ml}$ BSA. An aliquot $(30 \mu \mathrm{l})$ of the diluted sample was transferred to $6 \mathrm{ml}$ of $1.3 \%(\mathrm{wt} / \mathrm{vol})$ molten $\left(47^{\circ} \mathrm{C}\right)$ Bactoagar (Difco Laboratories) containing $0.8 \%$ (wt/vol) nutrient broth and $0.5 \%(\mathrm{wt} / \mathrm{vol}) \mathrm{NaCl}$ and poured into a Petri dish. The agar was allowed to solidify at room temperature, and bacterial viability was measured as the number of colonies formed after incubation at $37^{\circ} \mathrm{C}$ for $18-24 \mathrm{~h}$.

Measurement of bacterial growth. Because formation of colonies on solid nutrient agar represents growth occurring over many (18-24) hours, bacterial growth was also followed in liquid medium during the first few hours after BPI addition by measuring the optical density (550 $\mathrm{nm}$ ) in a spectrophotometer (Model 25; Beckman Instruments, Inc., Fullerton, CA) of an aliquot of the bacterial suspension after dilution $(1 / 10)$ into ice-cold isotonic saline.
Measurement of outer membrane permeability. Outer membrane permeability was measured by determining bacterial susceptibility to the normally impermeant drug actD in one of two ways: (a) Measurement of bacterial incorporation of ${ }^{14} \mathrm{C}$-labeled mixed amino acids into TCA precipitable material in the presence or absence of $50 \mu \mathrm{g} / \mathrm{ml} \mathrm{actD}$ as previously described $(2,3)$. (b) Assay of bacterial viability after incubation for $5 \mathrm{~min}$ in the presence or absence of $50 \mu \mathrm{g} / \mathrm{ml} \mathrm{actD}$ immediately before testing for cell viability on growth medium supplemented with $1 \mathrm{mg} / \mathrm{ml}$ BSA. The percentage of bacteria with a permeable outer membrane was calculated as: $\left[1-\left(\right.\right.$ bacterial $\left[{ }^{14} \mathrm{C}\right]$ a.a. incorp. + ActD/bacterial $\left[{ }^{14} \mathrm{C}\right]$ a.a. incorp. $\left.\left.-\mathrm{ActD}\right)\right] \times 100$ or $[1-$ (bacterial viability in BSA + ActD/bacterial viability in BSA - ActD)] $\times 100$. Similar results were obtained by the two methods.

Assay of BPI binding. BPI binding was determined by incubating bacteria with ${ }^{125}$ I-labeled human BPI (11). At the indicated times, an aliquot $\left(1 \times 10^{7}\right.$ cells) was centrifuged at $13,000 \mathrm{~g} / 3 \mathrm{~min}$ in an Eppendorf model 5414 microfuge (Brinkmann Instruments, Inc., Westbury, NY) and washed once with an equal volume of saline. Bound ${ }^{125} \mathrm{I}-$ human BPI was measured by determining the radioactivity in the washed bacteria (after resuspension and transfer to a fresh tube) using a gamma counter (model 1275; LKB Instruments, Inc., Gaithersburg, MD).

Measurement of amino acid uptake. E. coli $\mathrm{J} 5\left(4 \times 10^{7} / \mathrm{ml}\right)$ were preincubated for $10 \mathrm{~min}$ in the presence of $100 \mu \mathrm{g} / \mathrm{ml} \mathrm{chloramphenicol}$ at $37^{\circ} \mathrm{C}$ in the standard incubation medium. Human BPI was then added (time zero), and at the indicated time points, $\left[{ }^{3} \mathrm{H}\right]$ proline $(20$ $\mu \mathrm{Ci} / \mathrm{ml}$ final concentration) or ${ }^{14} \mathrm{C}$-mixed amino acids $(4 \mu \mathrm{Ci} / \mathrm{ml}$ final concentration) was added. After an additional 5-min incubation, the cells were filtered onto cellulose nitrate filters $(0.45-\mathrm{mm}$ pore size; Millipore Corp., Bedford, MA) and washed once with $5 \mathrm{ml}$ of $0.8 \%$ (wt/vol) buffered nutrient broth. The radioactivity entrapped in the filter was measured by liquid scintillation counting (5). To determine the amount of radioactivity binding nonspecifically to the bacteria and/or the filter, samples of $E$. coli were pretreated for $30 \mathrm{~min}$ with $10 \%$ formaldehyde before adding radioactive amino acids. These values were subtracted from all samples to calculate the actual uptake of amino acids.

Assay of cytoplasmic membrane permeability. Cytoplasmic membrane permeability was monitored by measuring the hydrolysis of added ONPG at $37^{\circ} \mathrm{C}(0.5 \mathrm{mg} / \mathrm{ml})$ by a strain of $E$. coli $(\mathrm{ML}-35)$ that contains cytoplasmic $\beta$-galactosidase but is lactose-permease deficient (16). Production of $o$-nitrophenol (ONP) was measured by determination of $A_{400}$ using a Beckman model DU-7 spectrophotometer after addition at various times of $500 \mu \mathrm{l}$ of $20 \mathrm{mM} \mathrm{NaOH}$ to $250 \mu$ l of the standard incubation mixture. Maximum rates of ONPG hydrolysis were obtained by disruption of $E$. coli by sonication $(4 \times 15$-s pulses on ice) using a micro-ultrasonic cell disrupter (Kontes Co., Vineland, NJ) at $75 \%$ of full strength

\section{Results}

\section{Dissociation of the bactericidal and permeability increasing effects of BPI}

The finding that the typically closely coupled effects of BPI on the $E$. coli envelope and growth (10) can be dissociated upon removal of $>80 \%$ of previously bound BPI by high concentrations of $\mathrm{Mg}^{2+}(8,9)$ prompted a search for additional means of exploring the relationship between the effects of BPI on the envelope and viability of $E$. coli. We have found that serum albumin provides a useful tool for the dissection of the sequential effects of BPI on $E$. coli.

Table I shows that the preaddition of $150 \mu \mathrm{g} / \mathrm{ml}$ of bovine serum albumin (BSA) (i.e., $\sim 0.3 \%$ of the serum albumin concentration in normal serum) nearly completely blocks the growth inhibitory (loss of colony formation) action of BPI on 
Table I. Dissociation of the Bactericidal and Permeability Increasing Activities of BPI

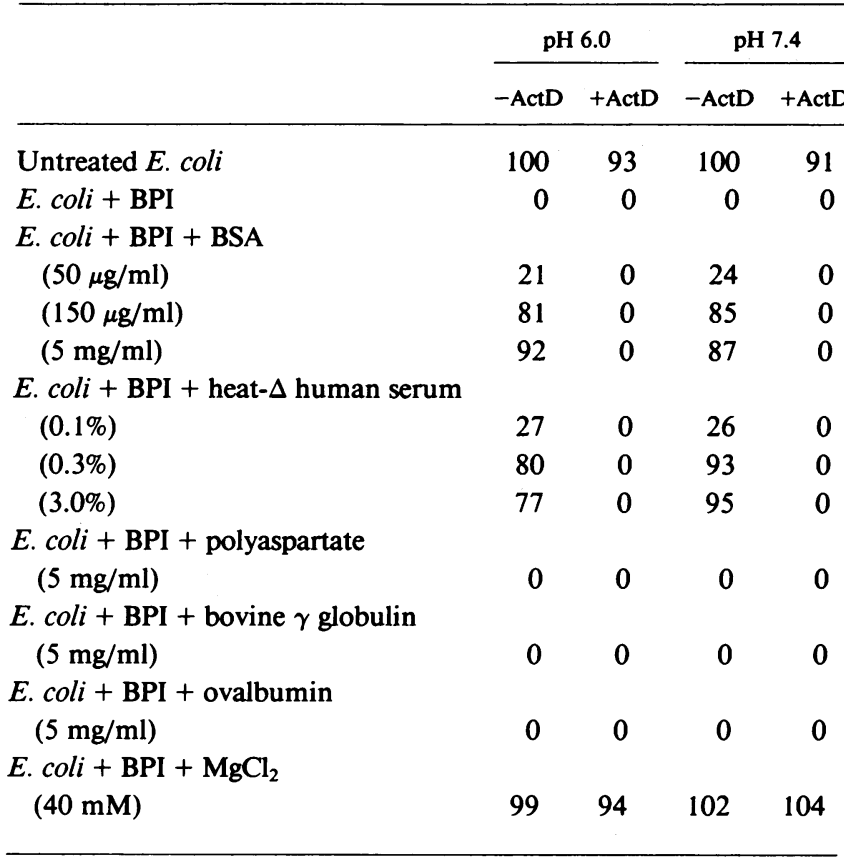

E. coli $\mathrm{J} 5\left(4 \times 10^{7} / \mathrm{ml}\right)$ were incubated at $37^{\circ} \mathrm{C}$ with or without 50 $\mu \mathrm{g} / \mathrm{ml}$ actD for $20 \mathrm{~min}$ in the standard incubation mixture that also contained 4.8 or $14 \mu \mathrm{g} / \mathrm{ml}$ of human BPI at $\mathrm{pH} 6.0$ and $\mathrm{pH} 7.4$ respectively, and either BSA, heat-treated human serum, polyaspartate, bovine $\gamma$ globulin, ovalbumin, or $\mathrm{MgCl}_{2}$ as indicated. Bacterial viability was measured as described in Methods with the same concentration of BSA, heat-treated human serum, polyaspartate, bovine $\gamma$ globulin, or ovalbumin added to the nutrient agar. The values shown represent the CFU in a given sample expressed as the percentage of the CFU in a bacterial sample at time zero. The minimal concentration of actD required to detect the BPI-induced increase in outer membrane permeability $(50 \mathrm{ng} / \mathrm{ml})$ was the same either in the presence or in the absence of BSA. Treatment of bacteria with the indicated agents without BPI had no effect on cell viability either in the absence or in the presence of actD. Data represent the mean of at least two experiments. Virtually identical results were observed when the concentration of $E$. coli was varied (range $10^{5}-10^{8}$ bacteria/ml).

$E$. coli that is produced under our usual experimental conditions. In contrast, serum albumin even at $\mathbf{3 0}$-fold higher concentrations, does not prevent the permeability increasing effect of BPI (sensitivity to normally impermeant actD) (Table I), nor the activation of the bacterial outer membrane phospholipase A (12) (not shown). Thus, these results demonstrate that the effects of BPI on the envelope and on the viability of $E$. coli can be completely. uncoupled.

Although the potency of human BPI during incubation in nutrient broth increases with a drop in pH (Table II), BSA is as effective at blocking the bactericidal activity of BPI at pH 6.0 as at 7.4 (Table I). The ability of BSA to block growth inhibition at either $\mathrm{pH} 6.0$ or 7.4 is not overcome by increasing the BPI dose (not shown). At doses corresponding to similar amounts of serum albumin added, heat treated (nonbactericidal) human serum, fatty acid and endotoxin free BSA, carboxymethylated BSA, BSA subjected to further purification by reverse phase HPLC, purified human serum albumin, and purified pig serum albumin (which lacks the $\mathrm{N}$-terminal copper
Table II. Effect of pH on Bactericidal Activity of Human BPI

\begin{tabular}{cccc}
\hline & \multicolumn{3}{c}{ Bacterial CFU (\%) } \\
\cline { 2 - 4 } Human BPI & $\mathrm{pH} \mathrm{6.0}$ & $\mathrm{pH} \mathrm{6.6}$ & $\mathrm{pH} \mathrm{7.4}$ \\
\hline$n g / 10^{7}$ & & & \\
0 & 100 & 100 & 100 \\
62.5 & $55 \pm 16$ & $\mathrm{ND}$ & $\mathrm{ND}$ \\
125 & $18 \pm 6$ & $58 \pm 10$ & $85 \pm 6$ \\
250 & $3 \pm 2$ & $21 \pm 4$ & $48 \pm 9$ \\
400 & $0.4 \pm 0.2$ & $3 \pm 2$ & $18 \pm 4$ \\
800 & 0 & 0 & $4 \pm 2$ \\
1200 & 0 & 0 & 0 \\
& & & \\
\hline
\end{tabular}

E. coli $\mathrm{J} 5\left(4 \times 10^{7} / \mathrm{ml}\right)$ were incubated with increasing amounts of purified human BPI in the standard incubation medium buffered with $20 \mathrm{mM} \mathrm{NaH}_{2} \mathrm{PO}_{4} / \mathrm{Na}_{2} \mathrm{HPO}_{4}$ to the indicated $\mathrm{pH}$. After a 15 min incubation at $37^{\circ} \mathrm{C}$, bacterial viability was determined as described in Methods. Data represent the mean \pm SEM of at least four experiments.

ion binding site) produce nearly identical effects on BPI action whereas other macromolecules, including ovalbumin, polyaspartate, bovine gamma globulin, heparin sulfate, and chondroitin sulfates $\mathrm{A}, \mathrm{B}$, or $\mathrm{C}$ do not inhibit the growth inhibitory activity of BPI under these conditions. The effect of the preaddition of serum albumin differs from the preaddition of $\mathrm{Mg}^{2+}$, a known antagonist of BPI action, which blocks both the bactericidal and envelope altering activities of BPI (6, Table I).

Effect of serum albumin and $\mathrm{MgCl}_{2}$ on BPI binding. To determine if serum albumin blocks the bactericidal activity of BPI by affecting binding of BPI to the target cell, as has been shown previously for at least one other cytotoxin (17), we measured binding of BPI to $E$. coli $\mathrm{J} 5$ in the presence or absence of $1 \mathrm{mg} / \mathrm{ml}$ serum albumin using ${ }^{125} I$ human BPI as a tracer (11). Fig. 1 shows that the rate and extent of binding of ${ }^{125}$ I human BPI are unaffected by serum albumin. In contrast, $80 \mathrm{mM} \mathrm{MgCl} 2$ nearly completely inhibits BPI binding, as has been shown previously (6) (Fig. 1).

Properties of BPI-treated E. coli during serum albuminmediated tolerance. The fact that serum albumin blocks bacterial killing without affecting either the initial binding or the outer envelope effects of BPI suggests that serum albumin renders the bacteria tolerant to the presence of BPI on the bacterial surface. To determine the duration of any sublethal effects exerted by BPI under these circumstances, we simultaneously monitored bacterial outer membrane permeability and growth during prolonged treatment of $E$. coli with BPI in the presence of serum albumin. BPI causes an almost immediate ( $<1 \mathrm{~min}$ ) breakdown of the outer membrane permeability barrier to actD that persists for up to $90 \mathrm{~min}$ (Fig. 2, top). During this period, the optical density of the bacterial suspension increases in a time-dependent manner at a rate approximately half that of untreated bacteria (Fig. 2, middle). In contrast, the number of colony forming units (CFU) during this same period does not increase (Fig. 2, bottom). Examination of the BPI-treated $E$. coli by light microscopy (in a bacterial counting chamber) showed that during the first 90 min after addition of BPI, the bacteria grow without separation of the daughter cells, forming progressively longer chains (not shown). After $\sim 90$ min incubation, the growth rate of the 


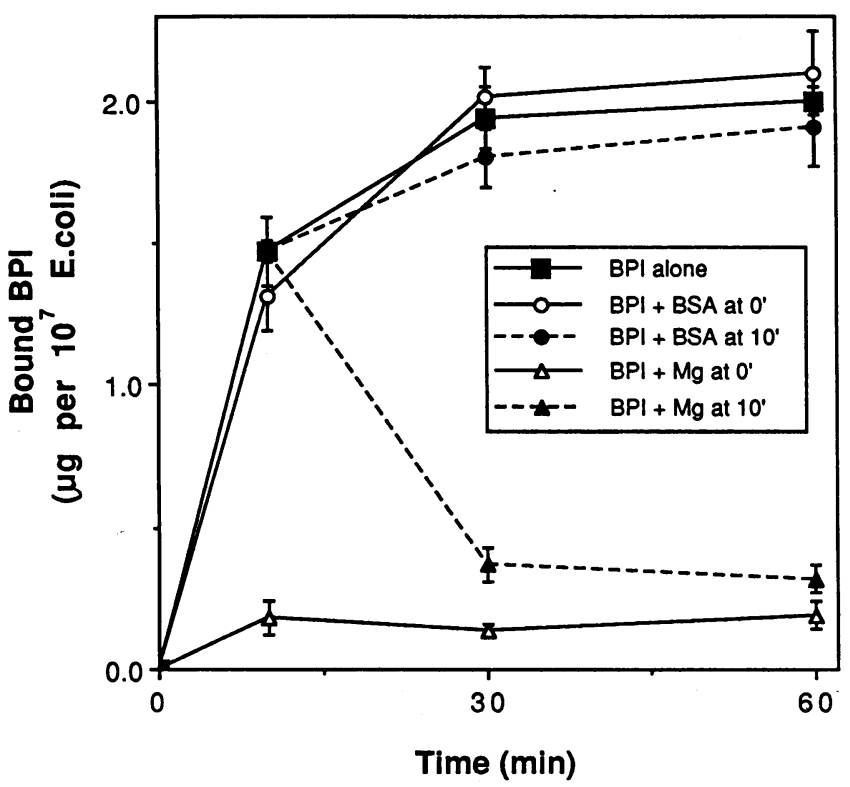

Figure 1. Effect of BSA or $\mathrm{MgCl}_{2}$ on the binding of BPI to E. coli. E. coli $\mathrm{J} 5\left(4 \times 10^{7} / \mathrm{ml}\right)$ were incubated at $37^{\circ} \mathrm{C}$ in the standard incubation medium at pH 6.0 with $10 \mu \mathrm{g} / \mathrm{ml}$ of ${ }^{125} \mathrm{I}$ human BPI. BSA (1 $\mathrm{mg} / \mathrm{ml}$ ) (circles) or $\mathrm{MgCl}_{2}(80 \mathrm{mM})$ (triangles) was added either immediately before (solid lines) or 10 min after (dotted lines) BPI addition. The amount of BPI bound to $E$. coli was measured at the indicated time points as described in Methods. Data shown represent the mean \pm SEM of three experiments. Identical results were obtained at pH 7.4.

BPI-treated bacteria (as assessed by either optical density or CFU) shifts to that of the untreated bacteria, coincident with restoration of the outer membrane permeability barrier (Fig. 2, compare upper panel with two lower panels) reflecting the emergence of an apparently normally growing bacterial population. However, this bacterial growth can only be sustained when serum albumin remains in the growth medium for at least $2.5 \mathrm{~h}$. Subsequent plating in nutrient agar without serum albumin before this time results in arrest of colony formation (Fig. 2, bottom, solid circles, dotted line).

Rescue of BPI-pretreated E. coli by serum albumin. The preceding experiments indicate that serum albumin blocks event(s) required for killing by BPI that are distinct from the initial surface binding and outer envelope alterations. To determine when killing occurs, $E$. coli were incubated with supralethal doses of BPI for increasing periods of time before addition of serum albumin and measurement of bacterial viability. BPI produces prompt arrest of bacterial growth during the preincubation without serum albumin both at $\mathrm{pH} 6.0$ (Fig. 2, middle panel) and at pH 7.4 (not shown). However, these treated bacteria can subsequently grow and form colonies upon addition of serum albumin (Fig. 3 ) despite the continued presence of BPI on the bacterial surface (Fig. 1). The concentration of serum albumin required for rescue (serum albumin added after BPI) and for prevention of growth arrest (serum albumin added before BPI) is the same (compare Table III with Table I). Moreover, the transient period of abnormal growth (chain formation) and actD sensitivity observed when serum albumin is added before BPI (Fig. 2) is also seen when BPI-pretreated $E$. coli are rescued by the subsequent addition
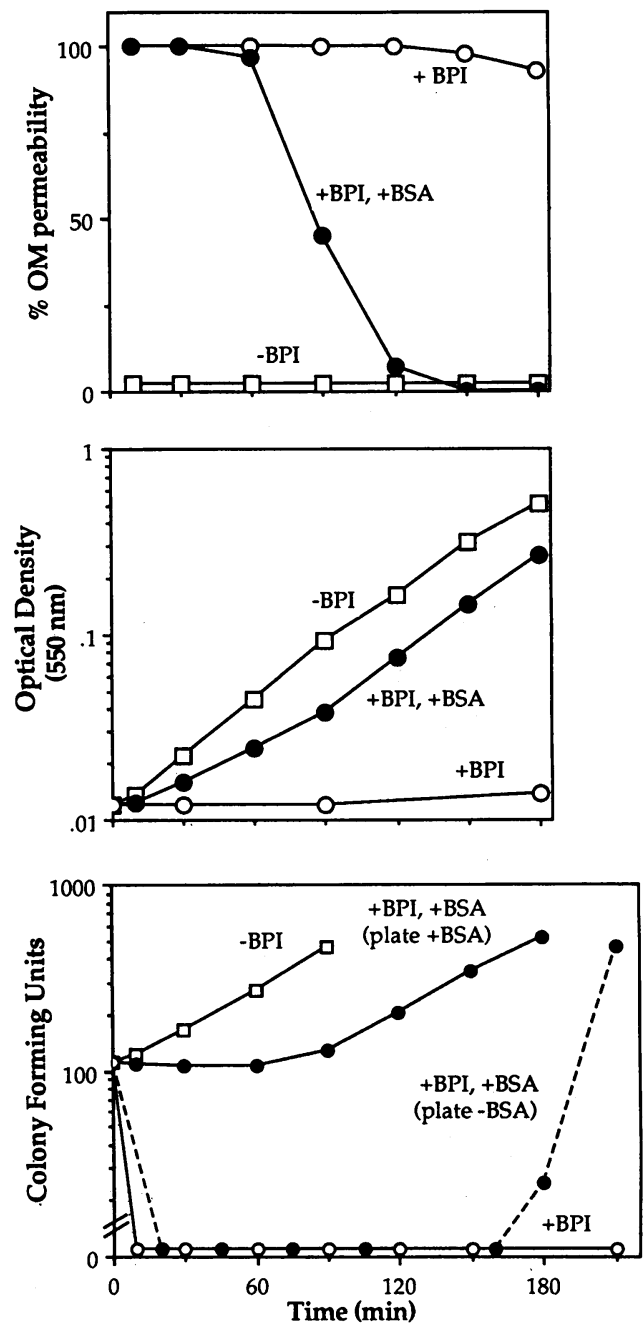

Figure 2. Properties of $E$. coli treated with BPI in the presence or absence of serum albumin. $E$. coli $\mathrm{J} 5\left(4 \times 10^{7} / \mathrm{ml}\right)$ were incubated at $37^{\circ} \mathrm{C}$ in the standard incubation medium at $\mathrm{pH} 6.0$ with (circles) or without (squares) purified human BPI $(4.8 \mu \mathrm{g} / \mathrm{ml})$ in the presence (closed symbols) or absence (open symbols) of $1 \mathrm{mg} / \mathrm{ml} \mathrm{BSA}$. At the indicated time points after BPI addition, aliquots were taken for measurement of: $(a)$ bacterial outer membrane $(\mathrm{OM})$ permeability (top) (b) absorbance at $550 \mathrm{~nm}$ after $10 \times$ dilution with saline (mid$d l e$ ), and (c) bacterial viability (i.e., colony-forming ability) (bottom) as described in Methods. Samples containing BSA were plated on nutrient agar (solid circles, broken line), and on nutrient agar supplemented with $1 \mathrm{mg} / \mathrm{ml} \mathrm{BSA}$ (solid circles, solid line). Virtually identical results were obtained when the incubation was carried out at $\mathrm{pH}$ 6.6 and $\mathrm{pH} 7.4$ or when the BSA concentration was varied (range $200 \mu \mathrm{g} / \mathrm{ml}$ to $5 \mathrm{mg} / \mathrm{ml}$ ). Data represent the mean of at least 2 closely similar experiments.

of serum albumin. Again, normal growth resumes after $\sim 90$ min incubation with serum albumin, coincident with restoration of the outer membrane permeability barrier (not shown).

Fig. 3 also shows that the number of BPI-pretreated bacteria that can be rescued by serum albumin declines with increasing time of preincubation of $E$. coli with human BPI. Loss of rescue occurs more rapidly at $\mathrm{pH} 6.0\left(t_{1 / 2}=10 \mathrm{~min}\right)$ than at pH $7.4\left(t_{1 / 2}=79 \mathrm{~min}\right)$ (Fig. 3, Table IV). These rates are not significantly altered by increasing BPI dose or by using rabbit 


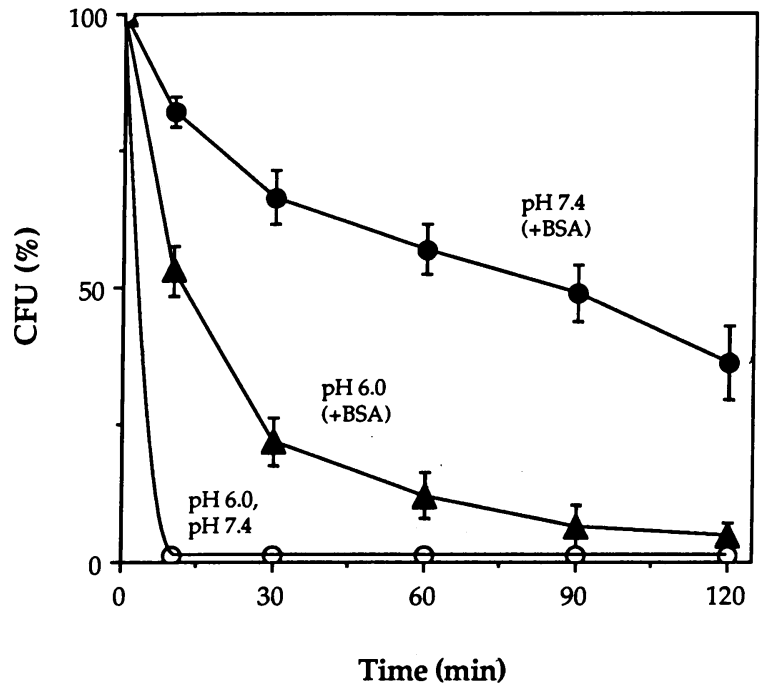

Figure 3. Time and $\mathrm{pH}$ dependent rescue of BPI-treated $E$. coli by serum albumin. E. coli $\mathrm{J} 5\left(4 \times 10^{7} / \mathrm{ml}\right)$ were incubated at $37^{\circ} \mathrm{C}$ in the standard incubation medium with purified human BPI $(4.8 \mu \mathrm{g}$ and $14 \mu \mathrm{g} / \mathrm{ml}$ at $\mathrm{pH} 6.0$ and 7.4 , respectively) in the standard incubation medium at either $\mathrm{pH} 6.0$ (triangles) or $\mathrm{pH} 7.4$ (circles). At the indicated times after BPI addition, bacterial CFU were measured as described in Methods by plating diluted samples in either nutrient agar (open symbols) or nutrient agar supplemented with $1 \mathrm{mg} / \mathrm{ml}$ BSA (closed symbols). Data shown represent the mean \pm SEM of at least five experiments.

rather than human BPI (Table IV), and identical results are obtained when heat-treated serum is used as a source of albumin. Inhibition of bacterial protein synthesis by pretreatment with chloramphenicol $(100 \mu \mathrm{g} / \mathrm{ml})$ also has no effect on the progression of BPI action from reversible to irreversible growth arrest (not shown). Similar rates of progression to serum albumin refractory growth inhibition are observed with several other strains of $E$. coli, including a strain bearing $\mathrm{K} 1$ capsule and a phospholipase-deficient (pldA ${ }^{-}$) mutant (14) that undergoes no phospholipid degradation during BPI treatment (Weiss, J., manuscript in preparation) (Table IV). How-

Table III. Dose Dependence of BSA-mediated Rescue of E. coli Pretreated with BPI

\begin{tabular}{cc}
\hline BSA concentration & Bacterial CFU \\
\hline$\mu g / m l$ & $\%$ \\
0 & 0 \\
15 & 0 \\
50 & $17 \pm 9.9$ \\
150 & $64 \pm 6.8$ \\
500 & $61 \pm 4.9$ \\
1500 & $66 \pm 3.1$
\end{tabular}

E. coli $\left(4 \times 10^{7} / \mathrm{ml}\right)$ were incubated with $14 \mu \mathrm{g} / \mathrm{ml}$ human BPI in the standard incubation medium at $\mathrm{pH}$ 7.4. After a 60-min incubation at $37^{\circ} \mathrm{C}$, bacterial $\mathrm{CFU}$ were determined as described in Methods by plating the bacteria on nutrient agar supplemented with increasing amounts of BSA. The data shown represent the mean \pm SEM of three experiments. Virtually identical results were observed when the concentration of $E$. coli was varied (range $10^{5}-10^{8}$ bacteria $/ \mathrm{ml}$ ).
Table IV. Rate of Killing of Various Strains of E. coli by BPI

\begin{tabular}{lcc}
\hline & $\mathrm{pH} 6.0$ & $\mathrm{pH} 7.4$ \\
\cline { 2 - 3 } \multicolumn{1}{c}{ Strain } & \multicolumn{2}{c}{$\begin{array}{c}t_{1 / 2} \text { (min) } \\
\text { using rabbit (human) } \mathrm{BPI}\end{array}$} \\
\hline E. coli $\mathrm{J} 5$ & $12(10)$ & $115(79)$ \\
E. coli $\mathrm{PL} 2$ & 9 & $49(84)$ \\
E. coli $\mathrm{ML}-35$ & $(2)$ & $36(13)$ \\
E. coli 09 & - & $53(12)$ \\
E. coli 1303 & 18 & 120 \\
E. coli 1602 & 16 & 91 \\
E. coli $0111: \mathrm{B} 4$ & - & 64 \\
E. coli $\left(\mathrm{K} 1^{+}\right)$ & - & $(51)$ \\
\hline
\end{tabular}

E. coli $\left(4 \times 10^{7} / \mathrm{ml}\right)$ were incubated at $37^{\circ} \mathrm{C}$ in the standard incubation medium with purified rabbit (or human) BPI (three times the minimal growth inhibitory dose) at either $\mathrm{pH} 6.0$ or $\mathrm{pH} 7.4$. After various incubation times, bacterial colony-forming units were measured as described in Methods by plating diluted samples in nutrient agar supplemented with $1 \mathrm{mg} / \mathrm{ml}$ BSA. For each bacterial strain treated with either human or rabbit BPI at the given $\mathrm{pH}$, at least two separate experiments were carried out, providing a minimum of 10 data points for each condition. The data were analyzed by linear regression to calculate the $t_{1 / 2}$ (i.e., the time required to produce $50 \%$ loss of viability in serum albumin supplemented medium). In all cases, the absolute value of the regression coefficient was $>0.97$.

ever, human BPI-treated $E$. coli 09 and ML-35 show a significantly more rapid progression to irreversible growth inhibition at both pH 6.0 and pH 7.4 (Table IV).

Irreversible growth arrest is accompanied by functional and structural damage to the cytoplasmic membrane. We have shown before that non-growing BPI-treated $E$. coli continue macromolecular synthesis $(1-5,7,8)$. Fig. 4 shows that the continued incorporation of mixed ${ }^{14} \mathrm{C}$-amino acids into protein by BPI-treated $E$. coli coincides with the serum albuminreversible phase of growth inhibition and that inhibition of amino acid incorporation occurs in a time-dependent fashion that parallels loss of rescue at both pH 7.4 (left) and pH 6.0 (right). However, amino acid incorporation appears to be inhibited before bacterial death (i.e., serum albumin refractory growth inhibition), analogous to the action of certain other cytotoxins $(18,19)$; this is more evident at pH 6.0 (Fig. 4, right). For example, after $10 \mathrm{~min}$ incubation at $\mathrm{pH} 6.0$, amino acid incorporation is reduced to $\sim 10 \%$ of control levels although nearly $60 \%$ of the bacteria can still be rescued by serum albumin. Addition of serum albumin at this time point partially reverses the inhibition of amino acid incorporation as well, restoring protein synthesis to a level that matches the number of viable organisms (Fig. 4, right). At later times (70 $\mathrm{min}$ ), when growth inhibition has become irreversible, amino acid incorporation does not resume upon serum albumin addition (Fig. 4, right).

To determine whether the observed decrease in protein synthesis is due to a lesion in the protein biosynthetic machinery or secondary to a block in amino acid transport, uptake of ${ }^{14} \mathrm{C}$ mixed amino acids into BPI-treated bacteria was measured. Table $\mathrm{V}$ shows that there is a sharp drop in net amino acid uptake within 5 min of BPI addition at $\mathrm{pH} \mathrm{6.0,} \mathrm{which}$ parallels the observed drop in protein synthesis. Similar results are obtained when uptake is measured in the absence of chlor- 


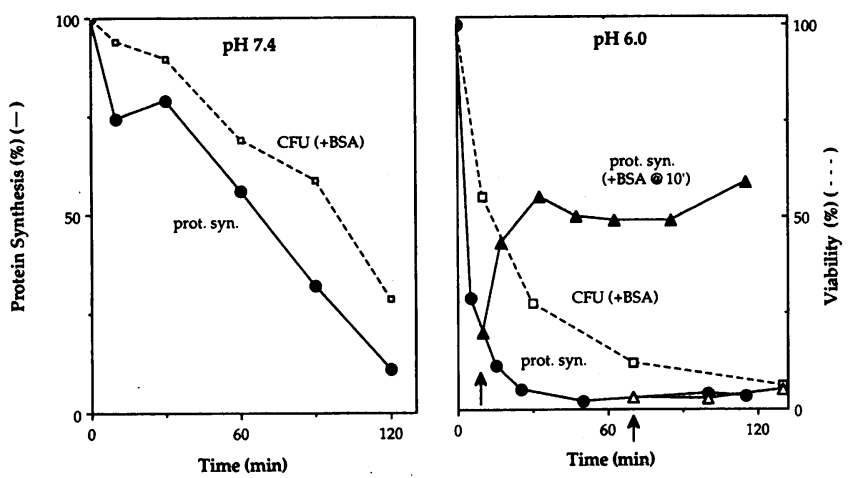

Figure 4. Correlation between irreversible growth inhibition by BPI and inhibition of bacterial protein synthesis at $\mathrm{pH} 6.0$ and $\mathrm{pH}$ 7.4. $E$. coli $\mathrm{J} 5\left(4 \times 10^{7}\right.$ per $\left.\mathrm{ml}\right)$ were incubated at $37^{\circ} \mathrm{C}$ with human BPI $(4.8 \mu \mathrm{g}$ and $14 \mu \mathrm{g} / \mathrm{ml}$ at pH 6.0 and 7.4 , respectively) in the standard incubation medium at either $\mathrm{pH} 7.4$ (left) or $\mathrm{pH} 6.0$ (right). At the indicated time points after BPI addition, samples were taken for measurement of bacterial viability and protein synthesis. Bacterial viability was measured as described in Methods by plating diluted samples into nutrient agar supplemented with $1 \mathrm{mg} / \mathrm{ml} \mathrm{BSA} \mathrm{(dashed}$ lines). Bacterial protein synthesis $\left({ }^{14} \mathrm{C}\right.$ mixed amino acid incorporation) was measured during an additional incubation for $10 \mathrm{~min}$ and after the addition of BSA either $10 \mathrm{~min}$ (closed triangles) or $70 \mathrm{~min}$ (open triangles) after BPI at pH 6.0 (indicated by the arrows). Incorporation of $\left[{ }^{14} \mathrm{C}\right]$ amino acids into acid-precipitable material has been corrected for growth of the bacterial suspension following BSA addition by dividing by the ratio of the $A_{550}$ of the bacterial suspension to the $A_{550}$ at time zero. Data shown are of one of at least three closely similar experiments.

amphenicol or when $\left[{ }^{3} \mathrm{H}\right]$ proline was used instead of ${ }^{14} \mathrm{C}$ mixed amino acids (not shown).

To ascertain whether the observed loss of amino acid uptake is accompanied by direct cytoplasmic membrane damage, we assessed cytoplasmic membrane integrity by measuring the rate of hydrolysis of exogenously added ONPG to ONP after treatment of $E$. coli ML-35 with BPI. Because $E$. coli ML-35 lacks lactose-permease, (passive) permeation of ONPG across the cytoplasmic membrane is the rate-limiting step in its hydrolysis by cytoplasmic $\beta$-galactosidase (16). Fig. 5 shows that

Table V. BPI Inhibits Amino Acid Uptake by E. coli at pH 6.0

\begin{tabular}{lcc}
\hline Sample & Amino acid incorporation & Amino acid uptake \\
& $\%$ & $\%$ \\
Untreated E. coli J5 & 100 & 100 \\
E. coli + BPI & & \\
$5 \mathrm{~min}$ & $17 \pm 2.3$ & $19 \pm 5.1$ \\
$10 \mathrm{~min}$ & $10 \pm 4.3$ & $7 \pm 1.9$ \\
$30 \mathrm{~min}$ & $6 \pm 4.3$ & $4 \pm 3.1$ \\
\hline
\end{tabular}

E. coli $\mathrm{J} 5\left(4 \times 10^{7} / \mathrm{ml}\right)$ were incubated in nutrient broth at $\mathrm{pH} 6.0$ with or without human BPI $(4.8 \mu \mathrm{g} / \mathrm{ml})$ for the indicated times. ${ }^{14} \mathrm{C}$ mixed amino acids were then added, and samples were incubated for an additional $5 \mathrm{~min}$. Bacterial uptake of $\left[{ }^{14} \mathrm{C}\right]$ amino acids and incorporation into protein were measured as described in Methods. Data are expressed as the percent of uptake or incorporation by an equivalent number of untreated bacteria. Values shown represent the mean \pm SEM of at least three experiments.

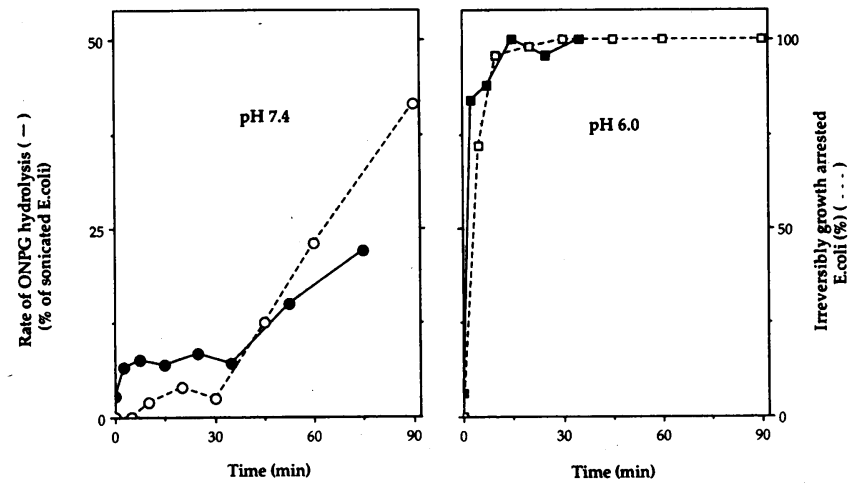

Figure 5. Correlation between irreversible growth inhibition and increased cytoplasmic membrane permeability in BPI-treated $E$. coli ML-35. E. coli ML-35 $\left(1 \times 10^{7}\right.$ per ml) were incubated at $37^{\circ} \mathrm{C}$ in the standard incubation medium with human BPI (10 $\mu \mathrm{g}$ and 30 $\mu \mathrm{g} / \mathrm{ml}$ at $\mathrm{pH} 6.0$ and 7.4 , respectively) either at $\mathrm{pH} 6.0$ (squares) or at pH 7.4 (circles) in the presence of $0.5 \mathrm{mg} / \mathrm{ml}$ ONPG. At the indicated times after BPI addition, aliquots were taken for measurement of $(a)$ cytoplasmic membrane permeability as described in Methods (closed symbols, solid lines), and (b) bacterial viability as described in Methods by plating diluted samples in nutrient agar supplemented with $1 \mathrm{mg} / \mathrm{ml} \mathrm{BSA} \mathrm{(open} \mathrm{symbols,} \mathrm{broken} \mathrm{line).} \mathrm{The} \mathrm{data} \mathrm{shown} \mathrm{are}$ of one of three closely similar experiments.

at pH 7.4 (left) and pH 6.0 (right), BPI treatment causes a time-dependent increase in the rate of ONP production that nearly exactly coincides with the time-dependent progression to irreversible growth inhibition. The maximal rate of ONPG hydrolysis seen after BPI treatment is approximately half the rate seen with sonicated bacteria.

\section{Discussion}

A prominent characteristic of the action of BPI on susceptible bacteria is that prompt growth arrest is accompanied by discrete outer envelope alterations but without initial loss of energy-dependent functions $(1-5,7,8)$. In fact, growth arrested $E$. coli, for at least one hour after the addition of a fully growth inhibitory dose of BPI, can restore the broken down permeability barrier by active biosynthesis of new LPS when treated with high concentrations of $\mathrm{Mg}^{2+}$ or trypsin (8). This remarkable preservation of integrated biochemical functions raises questions concerning the extent of damage by BPI that accounts for growth arrest and whether this damage suffices for bacterial death. Further, because removal of $>85 \%$ of bound BPI by either $\mathrm{Mg}^{2+}$ or trypsin and the subsequent repair of the outer envelope is not accompanied by resumption of growth (8-10), how close is the relationship between the envelope alterations and the lethal effects produced by BPI?

The use of micromolar concentrations of bovine or human serum albumin in this study has allowed us to address these questions and has provided several new insights into the antibacterial actions of BPI: $(a)$ initial binding and outer envelope alterations can be separated from bacterial growth arrest, $(b)$ large portions of the promptly growth inhibited $E$. coli in fact are not dead and can be rescued by serum albumin for extended periods of time, and $(c)$ ultimate bacterial death coincides with cytoplasmic membrane damage.

These conclusions rest on the following findings: $(a)$ When serum albumin is added before BPI, no growth inhibition 
occurs (Fig. 2, middle), except for transient abnormal growth in chains. However, BPI binding (Fig. 1) and the effects of BPI on the permeability barrier in the outer membrane (Table I, Fig. 2, top) and on bacterial phospholipolysis (12) are the same as without serum albumin. (b) Addition of serum albumin to the bacterial suspension at various times after BPI, or at the end of incubation to the culture medium, results in resumption of growth by gradually diminishing portions of the bacterial population that do not grow in the absence of serum albumin (Fig. 3). This rescue takes place despite the fact that BPI remains bound to the bacterial surface (Fig. 1) and the envelope alterations persist (until the surviving population outgrows these effects). (c) The time course of decrease in the population of BPI-treated $E$. coli that can be rescued by serum albumin parallels the decrease in bacterial amino acid transport (Table V) and incorporation into protein (Fig. 4). Further, Fig. 5 shows a coincident increase in the permeability of the cytoplasmic membrane of $E$. coli ML-35 to normally impermeant ONPG and in nonrescue by serum albumin. We have also shown recently that BPI inhibits $\mathrm{O}_{2}$ consumption in a time-dependent fashion (4).

Gram negative bacteria generally can survive and repair damage to the outer membrane but do not tolerate damage to the cytoplasmic membrane (20-26), the site of most of the bacterial biochemical machinery. It appears likely therefore that the progression from an initial phase of envelope alterations that are limited to the outer membrane, leaving the biochemical machinery intact, to irreversible growth arrest, i.e., bacterial death, reflects either direct or indirect BPI effects on cytoplasmic membrane function. Whether or not BPI actually reaches and damages the cytoplasmic membrane of intact $E$. coli or triggers secondary effects remains uncertain. However, In't Veld et al. (4) have shown recently that BPI blocks energy dependent solute uptake by isolated cytoplasmic membrane vesicles of $E$. coli and Bacillus subtilis, indicating that BPI can potentially cause direct cytoplasmic membrane damage similar to what is seen in the intact $E$. coli.

The rate of progression from reversible to irreversible growth inhibition in phosphate-buffered nutrient broth shows some strain to strain variation (Table IV) but in all cases is more rapid at pH 6.0 than at $\mathrm{pH}$ 7.4. Such a pH dependence of cytotoxicity is shared by several prokaryotic and eukaryotic toxins whose action depends on penetration across lipid bilayers as part of the target cell damage (27-34). We are now seeking evidence of penetration of a portion of bound BPI, or a biologically active fragment (12) further into the bacterial envelope. With these uncertainties in mind, we propose the working model of BPI actions depicted in Fig. 6.

How serum albumin protects $E$. coli from the lethal effects of BPI without affecting BPI binding and the outer membrane alterations is not yet clear. A range of other neutral and acidic macromolecules at high concentrations does not affect BPI action indicating at least some specificity of the serum albumin effect (Table I). Moreover, the effects of whole serum can be accounted for by its serum albumin content (Table I), indicating that other serum constituents do not affect BPI action in a similar manner.

Although the broad complexing properties of serum albumin $(35,36)$ make it likely that any given preparation is contaminated with other substances, the same effects of multiple preparations of serum albumin, including those derived from

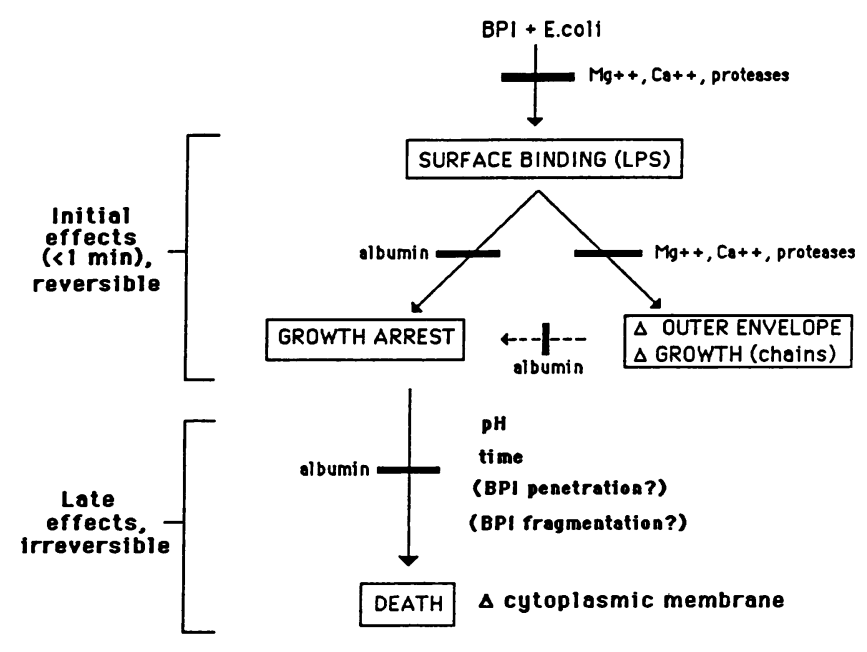

Figure 6. Model of BPI action. For further details, see text. $\Delta$ : altered.

bovine, pig, and human sources, those rendered fatty acid and endotoxin-free, and those subjected to further purification by reverse phase HPLC, favors the likelihood that the albumin effects are due to the protein itself. This effect is not attributable to the ability of serum albumin to complex and inactivate the membrane-lytic products of phospholipolysis because the same protective effect is provided $E$. coli 1303 , a mutant strain lacking a BPI-activatable phospholipase (14) (Table IV).

It is possible that serum albumin prevents the progression of BPI action to the cytoplasmic membrane by occupying bacterial envelope sites or by complexing with BPI itself. We have confirmed earlier findings of limited (1\%) binding of BSA to $E$. coli (37) but have obtained no positive evidence of an additional serum albumin interaction with the BPI-coated envelope (unpublished observations). However, these negative findings do not exclude the possibility that weak interactions between BPI and serum albumin do prevent BPI from reaching sites involved in later (lethal) consequences of BPI-binding. The fact that removal of serum albumin promptly re-establishes the growth inhibitory effects of the bound BPI (Fig. 1, bottom) shows that rescue requires the continued presence of serum albumin and may support the notion of weak interactions. Detection of such a subtle action of serum albumin is difficult not only because the serum albumin effect is produced at a molar ratio of serum albumin/BPI $>100$, but also because removal of $>85 \%$ of bound BPI by $\mathrm{Mg}^{2+}$ or trypsin does not prevent killing, suggesting that the lethal effects of BPI are produced by a small portion $(<15 \%)$ of the total bound BPI with which serum albumin may be interacting.

Finally, while serum albumin has served to demonstrate that BPI actually is not a rapidly bactericidal agent, it is evident that BPI produces a virtually instantaneous bacteriostasis. How such effective growth inhibition is produced without any other major functional impairment remains a challenging question. Another issue that is to be addressed is whether the action of intact PMN on ingested BPI-sensitive bacteria shows a temporal separation of sublethal and lethal effects analogous to that reported herein for the action of BPI. Studies in progress have already revealed that albumin can rescue $E$. coli ingested by intact PMN in a manner remarkably similar to what we have described here for isolated BPI. 


\section{Acknowledgments}

This work was supported by the U. S. Public Health Service grant R37DK 05472, and the American Cancer Society Grant MV-321. B. A. Mannion was supported by an National Institutes of Health training grant from the NIGMS: 5T32 GMO 7308.

\section{References}

1. Elsbach, P., and J. Weiss. 1988. Phagocytic cells: $\mathrm{O}_{2}$-independent antimicrobial systems. In Inflammation: Basic Principles and Clinical Correlates. J. I. Gallin, I. M. Goldstein, and R. Snyderman, editors. Raven Press, New York. 445-470.

2. Weiss, J., P. Elsbach, I. Olsson, and H. Odeberg. 1978. Purification and characterization of a potent bactericidal and membrane active protein from the granules of human polymorphonuclear leukocytes. $J$. Biol. Chem. 253:2664-2672.

3. Elsbach, P., J. Weiss, R. C. Franson, S. Beckerdite-Quagliata, A. Schneider, and L. Harris. 1979. Separation and purification of a potent bactericidal/permeability increasing protein and a closely related phospholipase A2 from rabbit polymorphonuclear leukocytes. Observations on their relationship. J. Biol. Chem. 254:11000-11009.

4. In't Veld, G., B. Mannion, J. Weiss, and P. Elsbach. 1988. The effects of the bactericidal/permeability increasing protein of polymorphonuclear leukocytes on isolated bacterial cytoplasmic membrane vesicles. Infect. Immun. 56:1203-1208.

5. Beckerdite, S., C. Mooney, J. Weiss, R. Franson, and P. Elsbach. 1974. Early and discrete changes in permeability of $E$. coli and certain other gram negative bacteria during killing by granulocytes. J. Exp. Med. 140:396-409.

6. Weiss, J., R. C. Franson, S. Beckerdite, K. Schmeidler, and P. Elsbach (1975). Partial characterization and purification of a rabbit granulocyte factor that increases permeability of $E$. coli. J. Clin. Invest. 55:33-42.

7. Elsbach, P., S. Beckerdite, P. Pettis, and R. C. Franson. 1974. Persistence of regulation of macromolecular synthesis by Escherichia coli during killing by disrupted granulocytes. Infect. Immun. 9:663-68.

8. Weiss, J., K. Muello, M. Victor, and P. Elsbach. 1984. The role of lipopolysaccharides in the action of the bactericidal/permeability increasing protein on the bacterial envelope. J. Immunol. 132:31093115.

9. Weiss, J., K. Schmeidler, S. Beckerdite-Quagliata, R. C. Franson, and P. Elsbach. 1976. Reversible envelope effects during and after killing of Escherichia coli by a highly purified rabbit polymorphonuclear leukocyte fraction. Biochim. Biophys. Acta. 436:154-169.

10. Weiss, J., M. Victor, and P. Elsbach. 1983. The role of charge and hydrophobic interactions in the action of the bactericidal/permeability increasing protein of neutrophils on Gram negative bacteria. $J$. Clin. Invest. 71:540-549.

11. Mannion, B. A., E. S. Kalatzis, J. Weiss, and P. Elsbach. 1989. Preferential binding of the bactericidal/permeability increasing protein to Escherichia coli. Implications and use as a means of purification. $J$. Immunol. 142:2807-2812.

12. Ooi, C. E., J. Weiss, P. Elsbach, B. Frangione, and B. Mannion. 1987. A $25 \mathrm{kDa} \mathrm{NH} \mathrm{NH}_{2}$-terminal fragment carries all the antibacterial activities of the human neutrophil bactericidal/permeability increasing protein. J. Biol. Chem. 262:14891-14894.

13. Simon, E. J., and D. van Praag. 1964. Inhibition of RNA synthesis in Escherichia coli by levorphanol. Proc. Natl. Acad. Sci. USA. 51:877-883.

14. DeGeus, P., I. van Die, H. Bergmans, J. Tommasson, and G. deHaas. 1983. Molecular cloning of pldA, the structural gene for outer membrane phospholipase of E. coli K12. Mol. Gen. Genet. 190:150155.

15. Lugtenberg, B., R. Peters, H. Bernheimer, and W. Berendsen. 1976. Influences of cultural conditions and mutations on the compo- sition of the outer membrane proteins of Escherichia coli. Mol. Gen. Genet. 147:251-262.

16. Lehrer, R. I., A. Barton, and T. Ganz. 1988. Concurrent assessment of inner and outer membrane permeabilization and bacteriolysis in $E$. coli by multiple wavelength spectrophotometry. $J$. Immunol. Methods. 108:153-158.

17. Lichtenstein, A. K., T. Ganz, T. Nguyen, M. E. Selsted, and R. I. Lehrer. 1988. Mechanism of target cytolysis by peptide defensins. J. Immunol. 140:2686-2694.

18. Dankert, J., S. M. Hammond, and W. A. Cramer. 1980. Reversal by trypsin of the inhibition of active transport by colicin E1. $J$. Bacteriol. 143:594-602.

19. Esser, A. F. 1980. Bactericidal activity of complement. Fed. Proc. 39:1755. (Abstr.)

20. Heppel, L. 1969. The effect of osmotic shock on release of bacterial proteins and on active transport. J. Gen. Physiol. 54:95s$113 \mathrm{~s}$.

21. Leive, L. 1965. A non-specific increase in permeability in Escherichia coli produced by EDTA. Proc. Natl. Acad. Sci. USA. 53:745750 .

22. Anderson, J. J., J. M. Wilson, and D. L. Oxender. 1979. Defective transport and other phenotypes of a periplasmic "leaky" mutant of Escherichia coli K12. J. Bacteriol. 140:351-358.

23. Vaara, M., and T. Vaara. 1983. Sensitization of Gram-negative bacteria to antibiotics and complement by a non-toxic oligopeptide. Nature (Lond.). 303:526-528.

24. Bhakdi, S., G. Kuller, M. Muhly, S. Fromm, G. Seibert, and J. Parrisius. 1987. Formation of transmural complement pores in serum-sensitive Escherichia coli. Infect. Immun. 55:206-210.

25. Feingold, D. S., J. N. Goldman, and H. M. Kuritz. 1968. Locus of the lethal event in the serum bactericidal reaction. J. Bacteriol. 96:2127-2131.

26. Dankert, J. R., and A. F. Esser. 1986. Complement-mediated killing of Escherichia coli: Dissipation of membrane potential by a C9-derived peptide. Biochemistry. 25:1094-1 100.

27. Sandvig, K., and S. Olsnes. 1980. Diphtheria entry into cells is facilitated by a low pH. J. Cell Biol. 87:828-832.

28. Draper, R. K., D. O. O'Keefe, M. Stookey, and J. Graves. 1984. Identification of a cold-sensitive step in the mechanism of modeccin action. J. Biol. Chem. 259:4083-4088.

29. Mannell, M. H., S.-P. Shia, M. Stookey, and R. K. Draper. 1984. Evidence for penetration of diphtheria toxin to the cytosol through a prelysosomal membrane. Infect. Immun. 44:145-150.

30. Morris, R. E., and C. B. Saelinger. 1986. Reduced temperature alters Pseudomonas exotoxin A entry into the mouse LM cell. Infect. Immun. 52:445-453.

31. Davidson, V. L., K. R. Brunden, and W. A. Cramer. 1985. Acidic $\mathrm{pH}$ requirement for insertion of colicin $\mathrm{E} 1$ into artificial membrane vesicles: Relevance to the mechanism of action of colicins and certain toxins. Proc. Natl. Acad. Sci. USA. 82:1386-1390.

32. Pattus, F., M. C. Martinez, B. Dargent, D. Cavard, R. Verger, and C. Lazdunski. 1983. Interaction of colicin A with phospholipid monolayers and liposomes. Biochemistry. 22:5698-5703.

33. Escuyer, V., P. Boquet, D. Perrin, C. Motecucco, and M. Mock. 1986. A pH induced increase in hydrophobicity as a possible step in the penetration of colicin E3 through bacterial membranes. J. Biol. Chem. 261:10891-10898.

34. O'Keefe, D. O., and R. J. Collier. 1989. Cloned diphtheria toxin within the periplasm of Escherichia coli causes lethal membrane damage at low pH. Proc. Natl. Acad. Sci. USA. 86:343-346.

35. Peters, T., Jr. 1985. Serum albumin. Adv. Protein Chem. 37:161-245.

36. Kragh-Hansen, U. 1981. Molecular aspects of ligand binding to serum albumin. Pharmacol. Rev. 33:17-53.

37. Myhre, E. B., and G. Kronvall. 1980. Demonstration of specific binding sites for human serum albumin in group $\mathrm{C}$ and $\mathrm{G}$ streptococci. Infect. Immun. 27:6-14. 